\title{
Lactobacilli with superoxide dismutase-like or catalase activity are more effective in alleviating inflammation in an inflammatory bowel disease mouse model
}

This article was published in the following Dove Press journal:

Drug Design, Development and Therapy

\author{
Anna Tomusiak-Plebanek' \\ Piotr Heczko' \\ Beata Skowron² \\ Agnieszka Baranowska ${ }^{2}$ \\ Krzysztof Okoń ${ }^{3}$ \\ Piotr J Thor ${ }^{2}$ \\ Magdalena Strus' \\ 'Department of Microbiology, \\ Jagiellonian University Medical \\ College, Poland; ${ }^{2}$ Department \\ of Pathophysiology, Jagiellonian \\ University Medical College, Poland; \\ ${ }^{3}$ Department of Pathomorphology, \\ Jagiellonian University Medical \\ College, Poland
}

\begin{abstract}
Purpose: Some lactobacilli, which possess superoxide dismutase-like activity and catalase activity naturally, have strong antioxidative properties. The aim of this study was to identify such strains and check which of them play a crucial role in alleviating intestinal inflammation.

Methods: We selected two Lactobacillus strains for use in animal studies: L. plantarum 30B (which has the highest catalase activity) and L. acidophilus 900 (which has the highest dismutaselike activity). Forty mice (C57B1/6J) were divided into four experimental groups with ten mice in each group. Group I (control group) was not supplemented with Lactobacillus, group II (catalase group) was orally supplemented with L. plantarum 30B, group III (dismutase-like group) was supplemented with L. acidophilus 900, and group IV (mixed group) was supplemented with both Lactobacillus strains. For 23 days, the temperature and body mass of each mouse were recorded and fecal samples for microbiological examination were collected. On day 23 , the animals were sacrificed, and their intestines were removed for microbiological and histopathological studies.
\end{abstract}

Results: Compared to the control group, the highest drop in the body temperature was observed in groups II $(P<0.05)$ and IV $(P<0.05)$. Similarly, groups II $(P<0.05)$ and IV $(P<0.05)$ had the highest drop in body mass. Moreover, histopathological evaluation of colon fragments showed intracryptic abscesses in these groups. Group III mice showed most limited degree of inflammation.

Conclusion: Lactobacillus strains with dismutase-like activity are more effective in alleviating intestinal inflammation than strains producing catalase, suggesting that superoxide anion radical decomposition is crucial in this process.

Keywords: probiotic strains, inflammatory bowel diseases, antioxidative enzymes, mouse model

\section{Introduction}

Inflammatory bowel diseases (IBD) are a group of chronic conditions of the gastrointestinal (GI) tract that comprise two principal types: Crohn's disease and ulcerative colitis. The pathogenesis of IBD remains unclear. Researchers have identified that many genetic, immunological, and environmental factors, such as intestinal microbiota, diet, and chemical agents present in food and in the environment, likely play a role in IBD development. ${ }^{1,2}$ One of the various possible mechanisms involved in the initiation and perpetuation of IBD is free radical reactions, such as the imbalance between the levels of pro-oxidants and antioxidants. ${ }^{3}$ In the intestinal inflammatory processes, immune cells
Correspondence: Magdalena Strus Department of Microbiology, Jagiellonian University Medical College, 18 Czysta Street, 3 I I2 I Cracow, Poland

Tel +48 I2 6332567

Fax +48 I2 4233924

Email mbstrus@cyf-kr.edu.pl 
contact antigens present in inflamed tissue and produce high levels of reactive oxygen species (ROS) such as hydroxyl radical $(\mathrm{OH})$, superoxide anion $\left(\mathrm{O}_{2}^{-}\right)$, and hydrogen peroxide $\left(\mathrm{H}_{2} \mathrm{O}_{2}\right) .{ }^{4}$ Exposure of the intestinal epithelial cells to ROS for a short period of time does not affect their function because they possess numerous protective mechanisms, including enzymes that inactivate ROS, such as catalase, peroxidase, or superoxide dismutase (SOD), and DNA repair mechanisms. However, in the case of chronic intestinal inflammation, the antioxidative protective mechanisms weaken, which leads to persistence of high ROS concentrations. This process damages the intestinal barrier, progresses the inflammation process, and injures the intestinal epithelium. ${ }^{5}$ Thus, increasing the activity of antioxidative enzymes in inflamed mucosa of patients with IBD may be one way of suppressing the ongoing inflammation.

Antioxidative enzymes such as SOD or catalase are produced by the host cells and also by some commensal bacteria, which continuously colonize the GI tract. ${ }^{6}$ The Lactobacillus represent the genus of commensal bacteria permanently colonizing gut mucosa that may help preserve the biological balance between the amount of ROS and the activity of the antioxidative enzymes synthesized by the bacteria. In fact, some species belonging to this genus, such as L. delbrueckii, L. gasseri, and L. acidophilus can transform toxic $\mathrm{O}_{2}^{-}$to less active $\mathrm{H}_{2} \mathrm{O}_{2}$ :

$$
2 \mathrm{O}_{2}^{-}+2 \mathrm{H}^{+} \rightarrow \mathrm{H}_{2} \mathrm{O}_{2}+\mathrm{O}_{2}
$$

These Lactobacillus strains release $\mathrm{H}_{2} \mathrm{O}_{2}$ into the extracellular space, which can be detected by appropriate qualitative and quantitative assays. Selected Lactobacillus strains do not produce typical superoxide dismutase, but they use another mechanism: the dismutation reaction that is catalyzed by transition metal ions such as $\mathrm{Mn}^{2+} .7,8$

In addition, other species of Lactobacillus, such as L. plantarum, produce manganese pseudocatalase that controls the transformation of $\mathrm{H}_{2} \mathrm{O}_{2}$ to water and oxygen. ${ }^{9}$

$$
2 \mathrm{H}_{2} \mathrm{O}_{2} \rightarrow 2 \mathrm{H}_{2} \mathrm{O}+\mathrm{O}_{2}
$$

The biological activity of this enzyme is similar to heme catalase, which is also present in other bacteria and eukaryotic organisms.

Because lactobacilli have distinct antioxidative properties and are regarded as safe for humans and used as probiotics, researchers are looking to lactobacilli to actively break down superoxide radicals and $\mathrm{H}_{2} \mathrm{O}_{2}$, thus restoring the oxidative-antioxidative balance in the intestinal mucosa. Thus far, studies using genetically modified lactobacilli expressing SOD show that administration of these strains positively influences the course of inflammation in animal models. ${ }^{10-12}$ Because the use of genetically modified bacteria in humans is not allowed, another approach was made by us to identify naturally occurring Lactobacillus strains with strong antioxidative properties. If these strains display antiinflammatory activity in sufficient amounts, they could then be used as active ingredients in future probiotic supplements. Such a postulate was raised by Mishra et al in their review paper. ${ }^{13}$ Therefore, the aim of this study was to evaluate antioxidative properties of lactobacilli that occur naturally in the alimentary tract, select strains showing the highest dismutase-like and/or catalase activity, and assess their influence on the course of the intestinal inflammation in a mouse model of IBD (C57B1/6J).

\section{Materials and methods}

\section{Bacterial strains}

Twenty-five lactobacilli strains were selected for the study that had been collected during the following research projects: QLGI-1999-00050 from FP7 project of UE; 3PO5E 09125, and PO5A 09429 from the Polish National Research Center.

Detailed characteristics of strains are shown in Table 1. Each strain was then evaluated for its antioxidative properties.

\section{Analysis of antioxidative properties Dismutase-like activity}

To evaluate the ability of the bacteria to degrade superoxide anion radical to $\mathrm{H}_{2} \mathrm{O}_{2}$, we used two methods: 1) semiquantitative Peroxide Test Strip method (Merck, Darmstadt, Germany) and 2) quantitative DetectX SOD Colorimetric Activity Kit method (Arbor Assays, Ann Arbor, MI, USA).

1. The Peroxide Test Strip indicates the presence of $\mathrm{H}_{2} \mathrm{O}_{2}$ by a color change on an indicator strip. The results are compared to a provided color scale. For this assay, Lactobacillus strains were cultured in MRS broth (Oxoid, Hampshire, UK) for 24 hours in aerobic conditions at $37^{\circ} \mathrm{C}$, and then the Peroxide Test Strip was performed as described by Strus et al. ${ }^{14}$ We measured $\mathrm{H}_{2} \mathrm{O}_{2}$ production in three time intervals: 0,2 , and 24 hours after the start.

2. The DetectX SOD Colorimetric Activity Kit quantitatively measures SOD activity in sonically disrupted bacterial cells. For the DetectX SOD test, Lactobacillus strains were suspended in $1 \mathrm{~mL}$ MRS broth to a final concentration of 


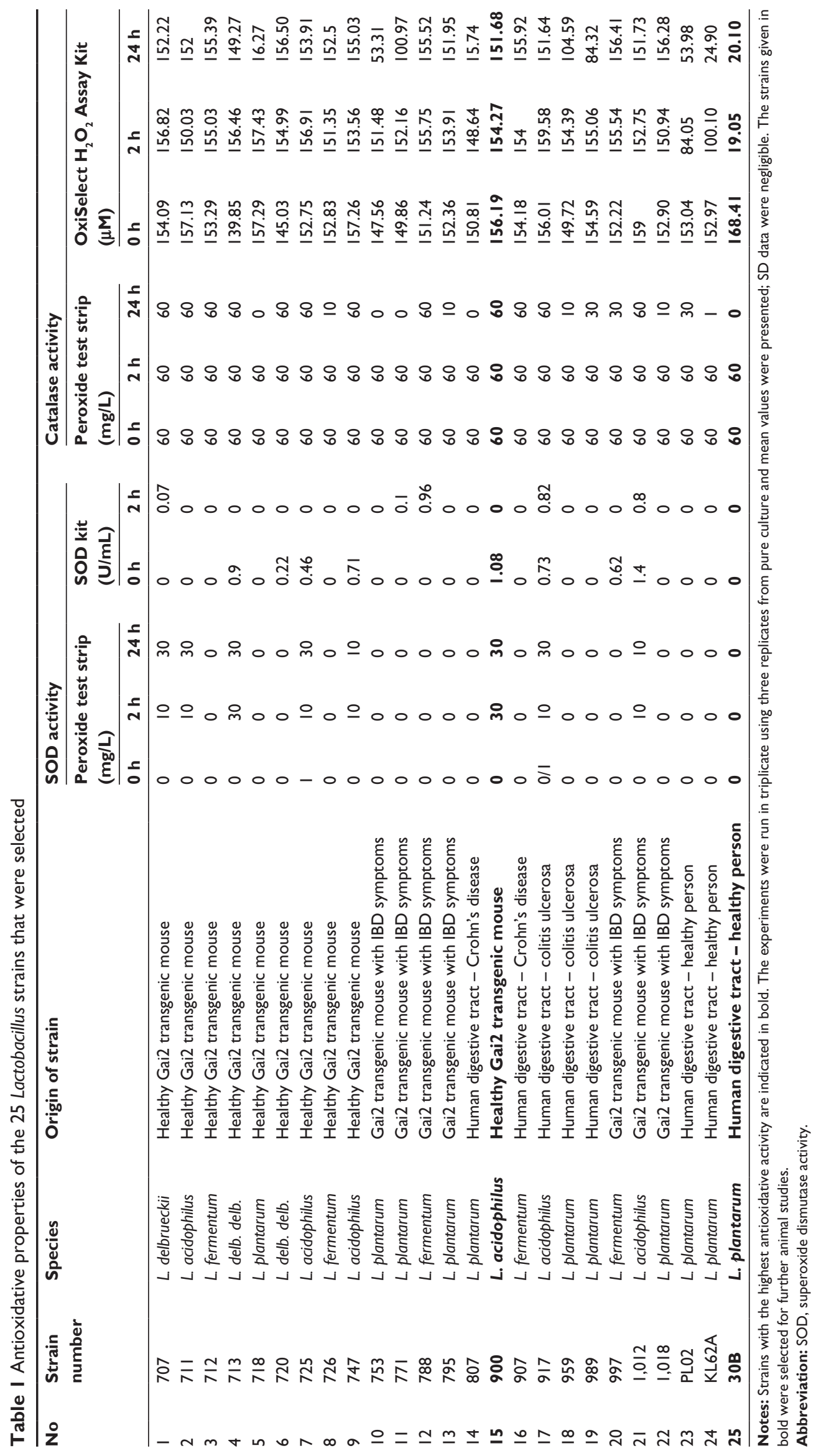


$1 \times 10^{8}$ colony-forming units $(\mathrm{CFU}) / \mathrm{mL}$. The culture was then incubated in aerobic conditions at $37^{\circ} \mathrm{C}$ for 2 hours. After incubation, the culture was centrifuged $(8,000 \mathrm{rpm}$, 5 minutes, $4^{\circ} \mathrm{C}$ ), the supernatant was removed, and the remaining cell pellet was washed with $4^{\circ} \mathrm{C}$ phosphate buffered saline (PBS; Gibco, Waltham, MA, USA). This procedure was repeated twice. The samples were then sonicated on ice ( 5 minutes, amplitude $50 \%$ ) and centrifuged $\left(8,000 \mathrm{rpm}, 5\right.$ minutes, $\left.4^{\circ} \mathrm{C}\right)$. Then, the supernatant was collected, and SOD activity was measured according to the manufacturer's instructions. Absorbance was read at $450 \mathrm{~nm}$ using a spectrophotometer (Awareness Technology Inc., Palm City, FL, USA). SOD concentration was calculated according to a standard curve.

\section{Catalase activity}

To examine catalase activity, we used the following methods: 1) semiquantitative Peroxide Test Strip method and 2) OxiSelect Hydrogen Peroxide Assay Kit method (Cell Biolabs, San Diego, CA, USA).

1. The semiquantitative Peroxide Test Strip was used after lactobacilli were cultured in $1 \mathrm{~mL}$ MRS broth for 24 hours in aerobic conditions at $37^{\circ} \mathrm{C}$. After centrifugation $\left(3,000 \mathrm{rpm}, 15\right.$ minutes at $\left.4^{\circ} \mathrm{C}\right)$, the supernatant was removed, and the cell sediment was resuspended in $1 \mathrm{~mL}$ fresh MRS broth with chemically pure $\mathrm{H}_{2} \mathrm{O}_{2}(\mathrm{POCH}$, Gliwice, Poland) at a final concentration of $60 \mathrm{mg} / \mathrm{L}$. The cultures were incubated at $37^{\circ} \mathrm{C}$ in aerobic conditions, and $\mathrm{H}_{2} \mathrm{O}_{2}$ concentration was measured at 0,2 , and 24 hours after the start.

2. For the OxiSelect Hydrogen Peroxide Assay Kit method, lactobacilli cultures were suspended in $1 \mathrm{~mL}$ MRS broth and incubated for 24 hours at $37^{\circ} \mathrm{C}$ in aerobic conditions. The cultures were centrifuged (3,000 rpm, 15 minutes), and the remaining cell sediment was resuspended in $1 \mathrm{~mL}$ PBS. Then $\mathrm{H}_{2} \mathrm{O}_{2}(30 \mathrm{mg} / \mathrm{L}$ final concentration) was added to all samples. We tested the catalase activity according to the manufacturer's instructions. The absorbance was measured at 0, 2, and 24 hours using a spectrophotometer (Awareness Technology Inc.) at $570 \mathrm{~nm}$. The final concentrations of $\mathrm{H}_{2} \mathrm{O}_{2}$ were calculated based on a reference curve.

\section{Animal studies}

\section{Animals}

All experimental procedures were approved by the Local Ethics Committee for Experiments on Animals of Jagiellonian University in Krakow and were done according to the Directive 2010/63/EU of the European Parliament and of the European Council, September 22, 2010, on the protection of animals used for scientific purposes.

The experiments were performed on homozygotic $\mathrm{C} 57 \mathrm{Bl} / 6 \mathrm{~J}$ mice with a mutation in the gene coding interleukin-10 $\left(\mathrm{IL}-10^{-/-}\right)$. Among the various rodent models for IBD, IL-10 deficient mice are widely used for studies investigating the pathogenesis of spontaneous, immune-mediated, intestinal inflammation. ${ }^{15-17}$ IL- $10^{-/-}$mice maintained in germ-free conditions do not develop intestinal inflammation. However, once colonized with conventional or specific pathogen-free (SPF) microbiota, IL-10 $0^{-/}$mice develop chronic intestinal inflammation. ${ }^{18}$ The animals were obtained from Jackson Laboratory (Bar Harbor, ME, USA), where they were kept in SPF conditions and colonized by artificially constructed microbiota. Five week-old mice were delivered to the Jagiellonian University Medical College animal facility in Anima-Lab (Poznań, Poland) transport cages with SPF guaranteed conditions. SPF standard was maintained throughout the experiments; the animals were kept in MICRO-ISOLATOR IIIH (Anima-Lab) cages fitted with specific air filters and fed sterile food and water. According to suggestions obtained from the Jackson Laboratories, the experiment was initiated when the body temperature of $70 \%$ of animals lowered from the normal of $37.5^{\circ} \mathrm{C}-38^{\circ} \mathrm{C}$ to $36.9^{\circ} \mathrm{C}-37.0^{\circ} \mathrm{C}$ and displayed other clinical symptoms, such as lower food intake and a visible worsening of physical condition, which suggest the beginning of intestinal inflammation. To achieve these precise data, body temperature of all animals was measured every 8 hours using rectal thermometry. Other parameters were noted simultaneously. The study was performed under permission 71/2013 of the local Jagiellonian University Bioethical Committee for Studies on Animals.

The study was performed on 40 animals, which were divided into four experimental groups, with ten mice in each group. Group I (control group) mice were not supplemented with lactobacilli. Group II (catalase group) mice were supplemented with human L. plantarum 30B strain, which showed a high catalase enzyme activity. Group III (dismutase group) animals were supplemented with human L. acidophilus 900 strain, which demonstrated high dismutase-like activity, and group IV (mix group) animals were supplemented with both L. plantarum 30B and L. acidophilus 900.

\section{Preparation of bacterial strains and animal supplementation regimens}

Bacterial suspensions for animal supplementation were prepared daily during the experiment by suspending a 24-hour 
culture in $10 \mathrm{~mL}$ PBS and adjusting the final concentration of bacterial cells to $1 \times 10^{8} \mathrm{CFU} / \mathrm{mL}$, as confirmed using a McFarland scale and a viable count method. ${ }^{19}$ During 23 days of the experiment, the animals were given the bacterial suspensions in autoclaved drinking water which was changed for new batch of the bacteria $3 \times$ daily, according to following schedule. Group II mice were given $100 \mu \mathrm{L}$ of L. plantarum strain $30 \mathrm{~B}$ suspension containing $1 \times 10^{8} \mathrm{CFU} /$ $\mathrm{mL}$ three times a day. Group III mice were given $100 \mu \mathrm{L}$ of L. acidophilus strain 900 suspension containing $1 \times 10^{8} \mathrm{CFU} /$ $\mathrm{mL}$ three times a day, whereas group IV mice were given a mixture of both Lactobacillus strains in equal proportions (50 $\mathrm{LL}$ L. acidophilus 900 plus $50 \mu \mathrm{L}$ L. plantarum 30B). Group I mice served as controls and were fed with sterile water without bacteria. Supplementation started on the first day of the experiment. On day 0 (the day before supplementation began) and on day 23 (the end of the experiment), fecal samples were collected from animals. Body temperature was measured on days $0,5,10,15,20$, and 23 using a rectal thermometer for rodents VIVARI (Warsaw, Poland). Body mass was measured on the same days. On the last day of the experiment, the animals were sacrificed by an overdose of pentobarbital (Morbital; Biowet, Pulawy, Poland), administered intraperitoneally at a concentration of $100 \mathrm{mg} / \mathrm{kg}$ of body mass. At necropsy, intestines were removed for microbiological and histopathological studies.
Quantitative examination of feces and intestinal tissue for groups of aerobic bacteria and lactobacilli On days 0 and 23, fecal samples were collected into sterile containers. The samples were weighed, placed in $10 \mathrm{~mL}$ Schaedler's broth (Difco, Detroit, MI, USA), and homogenized. Dilutions were made in Schaedler's broth and then from each dilution, $100 \mu \mathrm{L}$ samples were transferred onto appropriate agar media. Staphylococci were cultured for 24 hours at $37^{\circ} \mathrm{C}$ in aerobic conditions on Columbia Agar with 5\% sheep blood (Difco). Gram-negative bacteria were cultured on McConkey's agar (Biocorp, Warszawa, Poland) and enterococci were cultured on Bile EsculinAzide LABagar (Biocorp). Lactobacilli were cultured on MRS Agar (Oxoid) and cultivable anaerobic bacteria on Schaedler's agar both in strict anaerobic atmosphere using GENbox anaerobic system (bioMerieux, Craponne, France) at $37^{\circ} \mathrm{C}$ for 48 hours. To detect yeast-like fungi, Sabouraud Agar (Difco) was used at $37^{\circ} \mathrm{C}$ for 24 hours in aerobic conditions. Cultured bacteria were identified using the following API sets (bioMerieux): API 20E (Gram-negative rods), API Staph (staphylococci), API Strep (streptococci and enterococci), and API50CHL (lactic acid bacteria). Further species identification of strains, such as for L. plantarum and L. acidophilus, was done by PCR with species-specific primers. ${ }^{20}$ The primers used are listed in Table 2. Isolates identified as L. plantarum and L. acidophilus were compared with reference strains

Table 2 Species-specific primers used to identify Lactobacillus species (from Ref 19)

\begin{tabular}{|c|c|c|c|c|c|}
\hline $\begin{array}{l}\text { Primer } \\
\text { pair }\end{array}$ & Species & Primers & Target & Sequence $\left(5^{\prime}-3^{\prime}\right)$ & $\begin{array}{l}\text { PCR annealing } \\
\text { temperature } \\
\left({ }^{\circ} \mathrm{C}\right)\end{array}$ \\
\hline \multirow[t]{2}{*}{$\mathrm{I}$} & L. acidophilus & Aci I6SI & I6S gene & AGCTGAACCAACAGATTCAC & 62 \\
\hline & & $16 S \mid 1$ & & ACTACCAGGGTATCTAATCC & \\
\hline \multirow[t]{2}{*}{2} & L. crispatus & Cri I6SI & I6S gene & GTAATGACGTTAGGAAAGCG & 60 \\
\hline & & $16 S \mid I$ & & ACTACCAGGGTATCTAATCC & \\
\hline \multirow[t]{2}{*}{3} & L. gasseri & Gasl & 16S-23S spacer & GAGTGCGAGAGCACTAAAG & 55 \\
\hline & & Gasll & & CTATTTCAAGTTGAGTTTCTCT & \\
\hline \multirow[t]{2}{*}{4} & L. johnsonii & Joh I6SI & I6S gene & GAGCTTGCCTAGATGATTTTA & 57 \\
\hline & & $16 S \mid 1$ & & ACTACCAGGGTATCTAATCC & \\
\hline \multirow[t]{2}{*}{5} & L. plantarum & Lfpr & I6S-23S spacer & GCCGCCTAAGGTGGGACAGAT & 55 \\
\hline & & Planll & & TTACCTAACGGTAAATGCGA & \\
\hline \multirow[t]{2}{*}{6} & L. casei & Prl & 16S-23S spacer & CAGACTGAAAGTCTGACGG & 55 \\
\hline & & Casll & & GCGATGCGAATTTCTTTTTC & \\
\hline \multirow[t]{2}{*}{7} & L. zeae & Zeal & 16S-23S spacer & TGTTTAGTTTTGAGGGGACG & 58 \\
\hline & & Zeall & & ATGCGATGCGAATTTCTAAATT & \\
\hline \multirow[t]{2}{*}{8} & L. rhamnosus & Prl & 16S-23S spacer & CAGACTGAAAGTCTGACGG & 58 \\
\hline & & Rhall & & GCGATGCGAATTTCTATTATT & \\
\hline \multirow[t]{2}{*}{9} & L. reuteri & Lfpr & 16S-23S spacer & GCCGCCTAAGGTGGGACAGAT & 55 \\
\hline & & Reu & & AACACTCAAGGATTGTCTGA & \\
\hline \multirow[t]{2}{*}{10} & L. fermentum & Lfpr & I6S-23S spacer & GCCGCCTAAGGTGGGACAGAT & 55 \\
\hline & & Fermll & & CTGATCGTAGATCAGTCAAG & \\
\hline \multirow[t]{2}{*}{ II } & L. sharpeae & Shal & 16S-23S spacer & GATAATCATGTAAGAAACCGC & 58 \\
\hline & & Shall & & ATATTGTTGGTCGCGATTCG & \\
\hline
\end{tabular}


L. plantarum 30B and L. acidophilus 900 based on specific drug sensitivity patterns and growth inhibition zone diameters for the following antimicrobials (Oxoid): vancomycin (L. plantarum 30B strain was resistant to vancomycin; $L$. acidophilus 900 was sensitive, 21-22 mm diameter), ciprofloxacin (both L. plantarum 30B and L. acidophilus 900 strains were resistant), and trimethoprim-sulfamethoxazole (L. plantarum 30B was sensitive, 25-26 mm diameter; L. acidophilus 900 was resistant).

Samples from intestines were taken as follows. At necropsy, the GI tract from stomach cardia to anus was collected from each animal. The organ was transferred to a sterile Petri dish and then sectioned to obtain samples for microbiological, fluorescent in situ hybridization (FISH), and histopathological studies. The colon contents were removed from the lumen and transferred to a sterile test tube, weighed, placed in $10 \mathrm{~mL}$ Schaedler's broth, and plated on solid media as described earlier. The $1 \mathrm{~cm}$-long colon tissue samples were collected from the distal part of the large intestine, $3 \mathrm{~cm}$ from the anus. The samples were dissected using a sterile scalpel, washed thoroughly in $10 \mathrm{~mL}$ PBS (to remove remaining planktonic microbes), transferred to a test tube, weighed, and carefully fragmented in $1 \mathrm{~mL}$ Schaedler's broth using a glass mortar. Dilutions of the homogenized samples were made in Schaedler's broth, and then $100 \mu \mathrm{L}$ samples were plated on solid media and cultured as described earlier. Colony identification was performed using API tests (bioMerieux).

\section{Histopathological examination of intestinal tissue}

Histopathological examination was performed on the tissue fragments collected from the distal part of the large intestine that had been fixed in $10 \%$ formalin and embedded in paraffin. The tissues were sectioned to a thickness of $5 \mu \mathrm{m}$ using a cryostat and stained with hematoxylin (Merck) and eosin (Merck). Changes in the intensity of inflammation in the tissue were evaluated using a semiquantitative scale based on Asseman et al with the following modification. ${ }^{21}$ For the three parameters, granulocytic submucosal infiltrate, granulocytic transmural infiltrate, and intracryptic abscesses, appropriate point values from 0 to 2 were adjusted. A higher final result (the sum of values for all parameters between 0 and 6 points) indicates a worse clinical state.

\section{Fluorescent in situ hybridization}

A sample of the mouse colon was placed in $100 \mu \mathrm{L}$ sterile, distilled water and fragmented using a mortar. Then a $10 \mu \mathrm{L}$ volume from the mixture was placed on microscopic slide (Super Frost R Plus; Menzel Glaser, Braunschweig,
Germany) for FISH. The procedure and the probes used (EUB for all bacterial species; Lab158 for lactobacilli/enterococci; Enc for Enterococcus; and EC for Enterobacteriaceae) were in accordance with previously published methods. ${ }^{22-24}$

\section{Statistical analysis}

Statistical analysis was performed using SAS software for analysis of variance (ANOVA) and Tukey's test. The results are presented as averages \pm standard error (SE). Statistical significance was considered as follows: ${ }^{*} P<0.05$; $* * P<0.01$.

\section{Results}

\section{Antioxidative activity of Lactobacillus strains}

All collected strains showed extracellular $\mathrm{H}_{2} \mathrm{O}_{2}$ production at the time relevant to superoxide anion dismutation, although it was more commonly seen in L. acidophilus and L. delbrueckii strains than in L. plantarum strains. Strains L. acidophilus 900 and L. delbrueckii 713 displayed the highest superoxide anion radical dismutation activity in 2 hours. The L. plantarum strains, on the other hand, showed increased ability to degrade chemically pure $\mathrm{H}_{2} \mathrm{O}_{2}$ in comparison to the tested strains of other species. In 24 hours L. plantarum 718 , L. plantarum 753 , L. plantarum 771 , L. plantarum 807 , and L. plantarum 30B demonstrated the highest catalase activity. Detailed results of the performed tests are shown in Table 1. Based on them, strains L. acidophilus 900 and L. plantarum 30B were chosen for oral supplementation of the experimental animals.

\section{Observation of clinical parameters in animals}

Of the 40 experimental mice, 29 survived until the end of the experiment. Of the 11 animals that died, two belonged to group I, two were from group II, one was from group III, and six were from group IV. Except for one mouse from group IV which died on fifth day and one animal from group II which died on the 13th day, all other mice died at the end of the experiments, between days 21 and 23, which was related to progress in gut inflammation typical for this IBD animal model. Over the course of the experiment, body temperature dropped variously in the respective groups; for example, the drop in the body temperature of group I mice was visible until day 15 , at which point the temperature slowly rose (Figure 1). On day 23, the body temperature of group IV mice $(P<0.05)$ and group II $(0.01<P<0.05)$ was significantly lower than that of group I mice. Reduction in body temperature of group III mice occurred slowly and was 


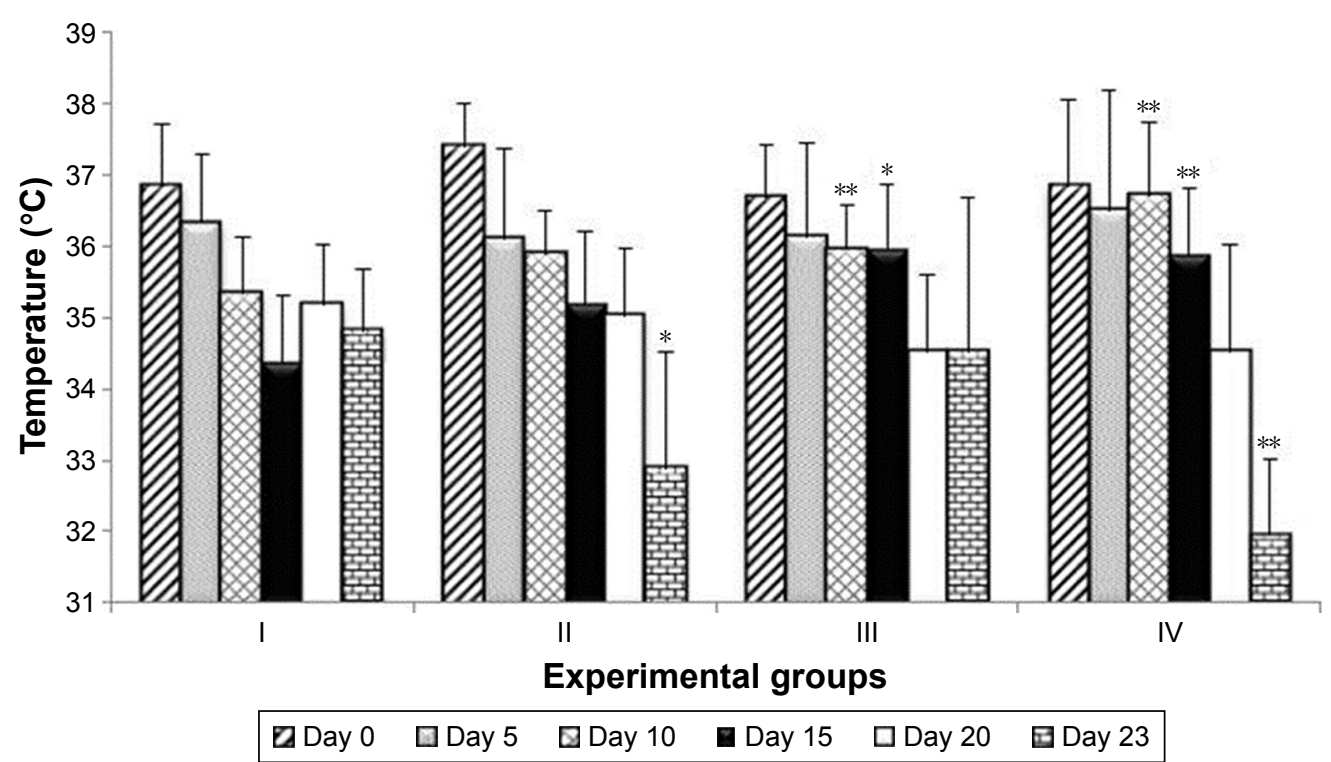

Figure I Changes in the animals' body temperature on selected study days.

Notes: Statistical significance was verified against group I (control) and considered as follows: $* P<0.05$; $* * P<0.0$ I.

not significantly different from that of group I (Figure 1). Over time, all groups experienced a gradual decrease in body mass. As with body temperature, group I displayed a decrease in body mass until day 15 , and then their body mass returned to the original value. The largest drop in body mass compared to group I was observed in group II $(0.01<P<0.05)$ and group IV $(0.01<P<0.05)$ on day 23 (Figure 2). Furthermore, the mortality rate in group IV was the highest (60\% died), which was observed after 21 days of the experiment and 63 supplementation doses of the L. plantarum 30B and L. acidophilus 900 mixture.

\section{Quantitative microbiological analyses of feces and intestinal tissues}

We compared the cultivable intestinal bacteria population related to inflammatory changes in experimental mice models of IBD. We found that the fecal samples collected from all groups on days 0 and 23 showed a significant increase in the numbers of Enterococcus spp., Enterobacteriaceae rods, and yeast-like fungi (Table 3). In addition, group II and group IV mice experienced a significant $(P<0.05)$ decrease in the numbers of staphylococci as compared to

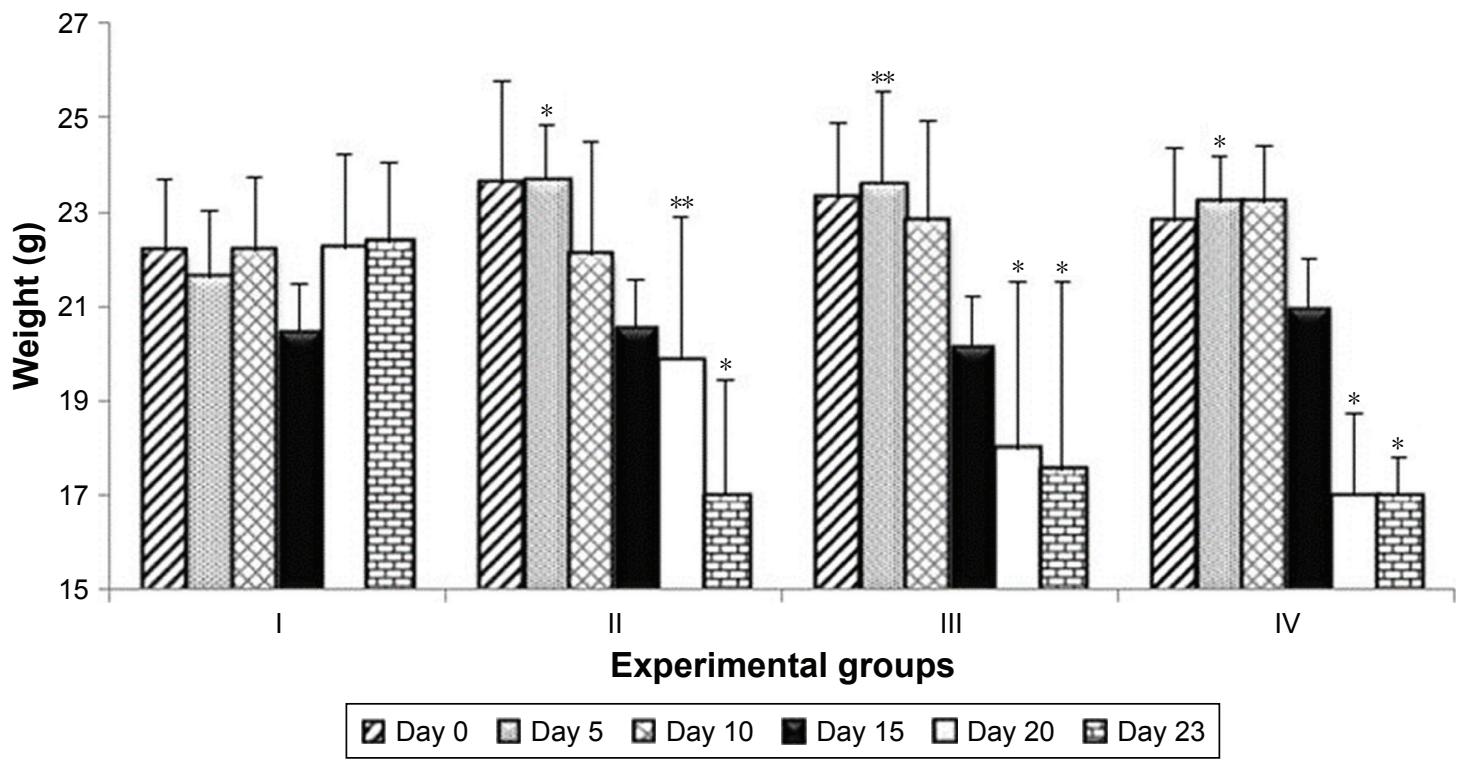

Figure 2 Changes in the animals' body mass on selected study days.

Notes: Statistical significance was verified against group I (control) and considered as follows: $* P<0.05 ; * * P<0.0$ I. 


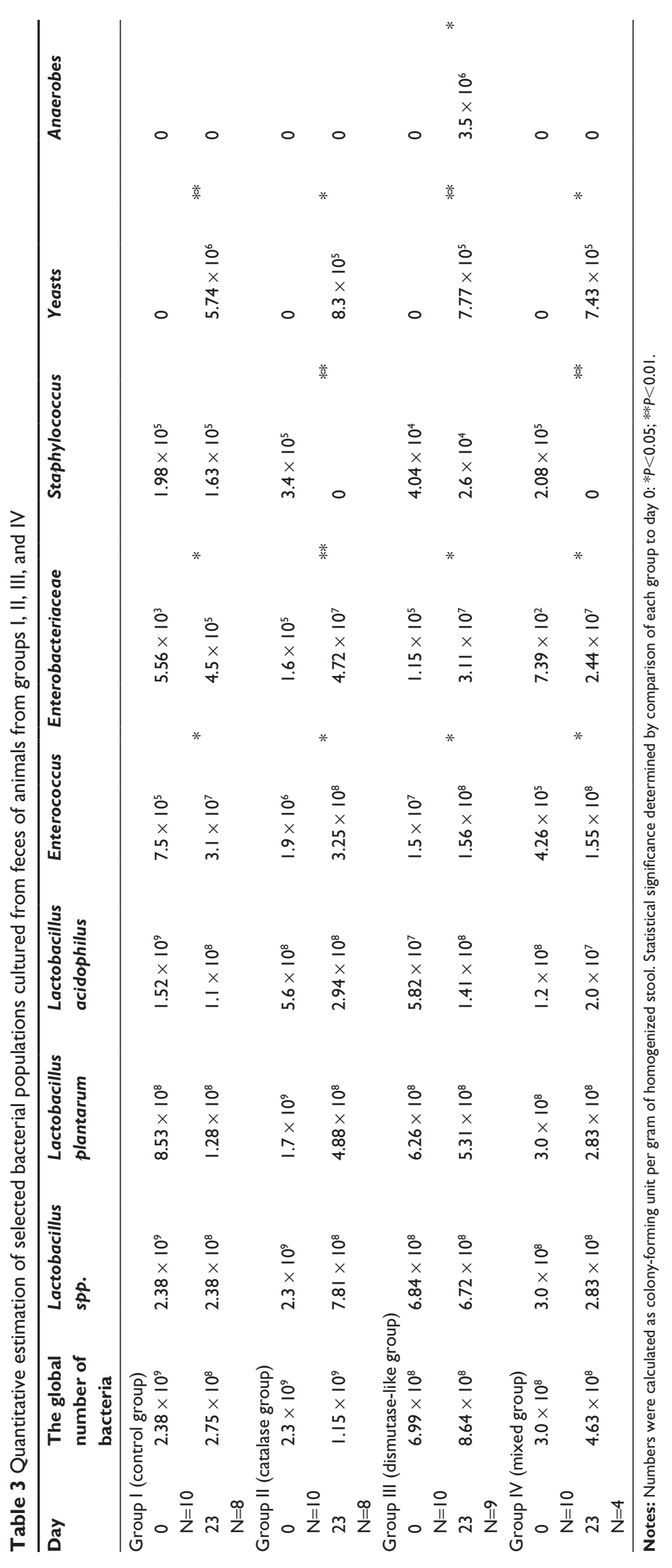


the control. The homogenized colon samples collected on day 23 of the experiment represented the mucosal adherent bacteria. In these samples, we observed that the populations of these major groups were comparable among experimental groups of mice, except for the mixed (IV) group. Colonic tissues taken from the mixed group contained significantly higher populations of bacteria from the Enterobacteriaceae family in comparison to that taken from other animal groups (Table 4). Group I animals showed a slight decrease in the total numbers of bacteria since they were not supplemented with lactobacilli. Cultivable anaerobic bacteria were found only in the feces of group IV animals by the end of the experiment.

\section{Histopathological examination of tissues and FISH}

Histopathological evaluation revealed that the most pronounced changes in granulocytic submucosal infiltration, transmural infiltration, and the presence of intracryptic abscesses were observed in groups II and IV, the histopathological scores of which were 4.75 and 4.8 , respectively. (Table 5) Group III achieved only a value of 2.75 , which indicates a less severe inflammatory response in these mice. The control group showed only mild inflammation scores. The colon tissues from group IV mice were the most severely affected. The histopathological examination of all the samples obtained from group IV showed intracryptic abscesses, which indicates an ongoing acute inflammatory process in the intestinal wall (Figure 3). Using FISH methods with specific probes, we demonstrated that Enterococcus populations in homogenized intestinal samples taken from group IV mice exceeded $1.0 \times 10^{4} \mathrm{CFU} / \mathrm{mL}$. This corresponded to the presence of intracryptic abscesses as observed in histopathological sections (Figure 4).

\section{Discussion}

In vitro studies on the antioxidative properties of lactobacilli were performed using strains originating from human or mouse GI tracts. Independent of their origin, L. plantarum strains demonstrated an ability to break down $\mathrm{H}_{2} \mathrm{O}_{2}$, which requires catalase enzyme activity. In fact, the mechanisms and uses of the antioxidative properties of this species have been studied frequently. ${ }^{25-27}$ On the other hand, we found that L. acidophilus and L. delbrueckii strains had the highest activity for liberation of extracellular $\mathrm{H}_{2} \mathrm{O}_{2}$, which requires superoxide anion dismutation. Thus, in mixed populations, for example in gut microbiota, some Lactobacillus strains carry out the superoxide anion radical dismutation to $\mathrm{H}_{2} \mathrm{O}_{2}$, while other lactobacilli have catalase and can degrade $\mathrm{H}_{2} \mathrm{O}_{2}$ to oxygen and water. From the 25 lactobacilli evaluated in this study, the highest catalase activity was observed in the human L. plantarum 30B strain, and the strongest superoxide anion dismutation was observed in the human strain L. acidophilus 900. We chose these two strains of human origin for in vivo experiments because of their expected future application. As far as we know, all published studies on the influence of lactobacilli on experimental chronic colitis in mice models were performed using human strains.

In the animal model of IBD, we observed that the strain L. acidophilus 900 with dismutase-like activity is more effective in suppressing the inflammatory process than the L. plantarum 30B, which produces catalase.

Table 4 Quantitative differences among populations of selected microbial groups and taxa (CFU/g) isolated from colon tissue on the 23 rd day of the experiment

\begin{tabular}{|c|c|c|c|c|c|}
\hline \multirow{2}{*}{$\begin{array}{l}\text { Selected microbial } \\
\text { groups }\end{array}$} & \multicolumn{4}{|c|}{ Number of bacteria (CFU/g tissue) } & \multirow[t]{2}{*}{ Statistical significance } \\
\hline & $\begin{array}{l}\text { Group I } \\
\text { (control) } \\
(n=8)\end{array}$ & $\begin{array}{l}\text { Group II } \\
\text { (catalase) } \\
(n=8)\end{array}$ & $\begin{array}{l}\text { Group III } \\
\text { (dismutation) } \\
(n=9)\end{array}$ & $\begin{array}{l}\text { Group IV } \\
\text { (mix) } \\
(n=4)\end{array}$ & \\
\hline Total bacterial population & $6.1 \times 10^{6}$ & $4.6 \times 10^{6}$ & $5.5 \times 10^{6}$ & $3.3 \times 10^{6}$ & \\
\hline Lactobacillus spp. & $5.9 \times 10^{6}$ & $3.7 \times 10^{6}$ & $1.6 \times 10^{6}$ & $4.1 \times 10^{5}$ & \\
\hline L. plantarum & $1.5 \times 10^{6}$ & $6.0 \times 10^{4}$ & $1.4 \times 10^{6}$ & $3.7 \times 10^{5}$ & \\
\hline L. acidophilus & $4.4 \times 10^{6}$ & $3.6 \times 10^{6}$ & $2.2 \times 10^{5}$ & $4.7 \times 10^{4}$ & \\
\hline Enterococcus spp. & $1.5 \times 10^{5}$ & $6.8 \times 10^{5}$ & $1.2 \times 10^{6}$ & $2.6 \times 10^{6}$ & \\
\hline Enterobacteriaceae & $9.9 \times 10^{4}$ & $2.0 \times 10^{5}$ & $2.6 \times 10^{6}$ & $2.3 \times 10^{7}$ & $\begin{array}{l}\text { *(between groups II and IV) } \\
\text { **(between groups I and IV) }\end{array}$ \\
\hline Staphylococcus spp. & $3.0 \times 10^{2}$ & 0 & $6.6 \times 10^{2}$ & 0 & \\
\hline Yeasts & $1.1 \times 10^{4}$ & $1.2 \times 10^{3}$ & $3.9 \times 10^{4}$ & $1.4 \times 10^{3}$ & \\
\hline Anaerobes & 0 & 0 & 0 & 0 & \\
\hline
\end{tabular}

Notes: Statistical significance: $* P<0.05 ; * * P<0.01$. A value of 0 indicates populations below $I \times 10^{2} \mathrm{CFU}$ (due to the limit of the viable count method). Abbreviation: CFU, colony-forming unit. 
Table 5 Histopathological examination of inflammatory changes in the intestinal tissues of the tested mice

\begin{tabular}{|c|c|c|c|c|c|c|c|}
\hline $\begin{array}{l}\text { Group/number } \\
\text { of mice in the } \\
\text { group }\end{array}$ & $\begin{array}{l}\text { Granulocytic } \\
\text { infiltration in the } \\
\text { intestinal wall }\end{array}$ & $\begin{array}{l}\text { Granulocytic } \\
\text { exudation in } \\
\text { the lumen }\end{array}$ & $\begin{array}{l}\text { Presence } \\
\text { of crypt } \\
\text { abscesses }\end{array}$ & $\begin{array}{l}\text { The total } \\
\text { number } \\
\text { of points }\end{array}$ & $\begin{array}{l}\text { Average } \\
\text { number } \\
\text { of points }\end{array}$ & SD & Comments \\
\hline $1 / 1$ & 0 & 0 & 0 & 0 & 0.1 & 0.353 & - \\
\hline $1 / 2$ & 0 & 0 & 0 & 0 & & & - \\
\hline $1 / 3$ & 0 & 0 & 0 & 0 & & & - \\
\hline $1 / 4$ & 0 & 0 & 0 & 0 & & & - \\
\hline $1 / 5$ & 0 & 0 & 0 & 0 & & & - \\
\hline $1 / 6$ & I & 0 & 0 & I & & & - \\
\hline $1 / 7$ & 0 & 0 & 0 & 0 & & & - \\
\hline $1 / 8$ & 0 & 0 & 0 & 0 & & & - \\
\hline $1 / 9$ & Death & Death & Death & Death & & & Death on day 18 \\
\hline $1 / 10$ & Death & Death & Death & Death & & & Death on day 17 \\
\hline II/I & 2 & 2 & 2 & 6 & 4.75 & 1.112 & - \\
\hline $\mathrm{II} / 2$ & - & - & - & - & & & Not done \\
\hline $\mathrm{II} / 3$ & 2 & 2 & 1 & 5 & & & - \\
\hline II/4 & 2 & 2 & 1 & 5 & & & - \\
\hline II/5 & 2 & 2 & 2 & 6 & & & - \\
\hline II/6 & I & I & 1 & 3 & & & - \\
\hline II/7 & 2 & 1 & 1 & 4 & & & - \\
\hline $\mathrm{II} / 8$ & 2 & I & 1 & 4 & & & - \\
\hline $11 / 9$ & Death & Death & Death & Death & & & Death on day 13 \\
\hline $11 / 10$ & Death & Death & Death & Death & & & Death on day 20 \\
\hline III/I & 2 & 2 & 0 & 4 & 2.75 & 1.164 & - \\
\hline $\mathrm{III} / 2$ & I & 1 & 0 & 2 & & & - \\
\hline $111 / 3$ & I & 0 & 0 & 1 & & & - \\
\hline $\mathrm{III} / 4$ & I & 1 & 0 & 2 & & & - \\
\hline $\mathrm{III} / 5$ & I & 0 & 1 & 2 & & & - \\
\hline III/6 & - & - & - & - & & & Not done \\
\hline $\mathrm{III} / 7$ & 2 & I & 1 & 4 & & & - \\
\hline $111 / 8$ & 2 & 1 & 1 & 4 & & & - \\
\hline $111 / 9$ & I & 1 & 1 & 3 & & & - \\
\hline $\mathrm{III} / \mathrm{IO}$ & Death & Death & Death & Death & & & Death on day 22 \\
\hline IV/I & 2 & 2 & 2 & 6 & 4.8 & 1.5 & - \\
\hline $\mathrm{IV} / 2$ & I & 2 & 1 & 4 & & & - \\
\hline $\mathrm{IV} / 3$ & I & 1 & 1 & 3 & & & - \\
\hline IV/4 & 2 & 2 & 2 & 6 & & & - \\
\hline $\mathrm{IV} / 5$ & Death & Death & Death & Death & & & Death on day 5 \\
\hline $\mathrm{IV} / 6$ & Death & Death & Death & Death & & & Death on day 21 \\
\hline IV/7 & Death & Death & Death & Death & & & Death on day 22 \\
\hline $\mathrm{IV} / 8$ & Death & Death & Death & Death & & & Death on day 22 \\
\hline $\mathrm{IV} / 9$ & Death & Death & Death & Death & & & Death on day 22 \\
\hline $\mathrm{IV} / \mathrm{IO}$ & Death & Death & Death & Death & & & Death on day 22 \\
\hline
\end{tabular}

Notes: Samples for histological evaluation were obtained at necropsy performed on day 23. Histological evaluation is reported in a 0-6 graded scale. Granulocytic infiltration in the intestinal wall: 0 - none, I - scanty, 2 - abundant. Granulocytic exudation in the lumen: 0 - none, I - sparse, 2 - profuse. Intracryptic abscesses: 0 - none, I - single, 2 - numerous.

This anti-inflammatory effect was principally observed during the initial phase of the study when both mouse body temperature and mass were measured. The drop in these parameters was much slower in mice supplemented with L. acidophilus 900 than in mice fed with catalase-producing lactobacilli or a mixed population of lactobacilli.

Oxidative stress in mucosa inflammation is an outcome of antioxidant depletion and oxidant/antioxidant imbalance. Under such conditions, an antioxidant system will not provide protection from the ROS-induced oxidative modification of lipids and proteins. In such situation, bacteria producing antioxidant enzymes attached to mucosa may interfere with this imbalance providing exogenous antioxidant enzymes to the underlying inflamed tissue. It is likely that the process of inactivating ROS by transforming superoxide anion radical to a less toxic $\mathrm{H}_{2} \mathrm{O}_{2}$ plays a more important role in reducing inflammation than the process of converting $\mathrm{H}_{2} \mathrm{O}_{2}$ to oxygen and water. This may be explained by data showing 

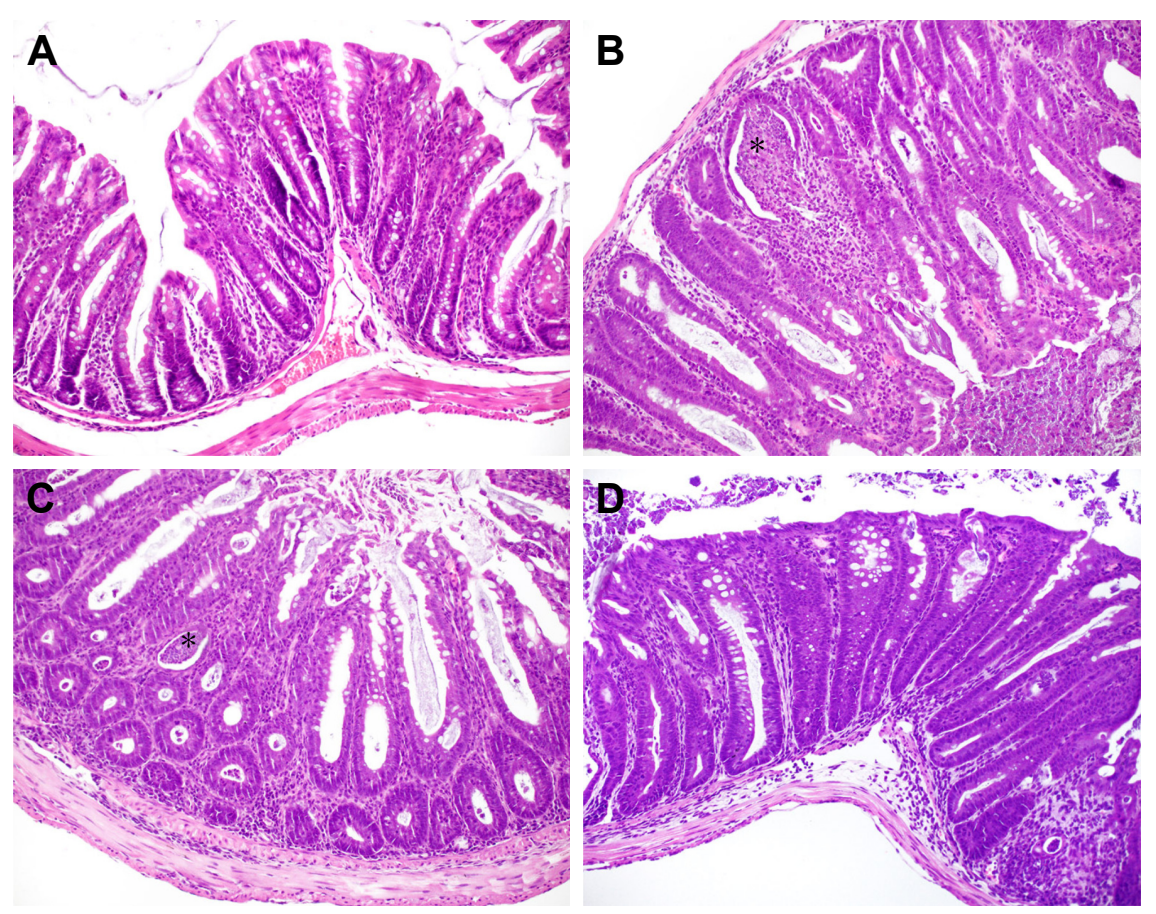

Figure 3 Histopathological section of intestinal walls.

Notes: (A) Normal structure of intestines in control group. H\&E, 200×. (B) Significantly inflamed intestine in group II; with mixed-cellular infiltrate in the mucosa, some crypts contain micro abscesses (*). H\&E, 200×. (C) Significant interstitial inflammation and micro abscesses (*) were observed in group III. H\&E, 200×. (D) Group IV mice showed mild infiltrate in the lamina propria, composed chiefly of mononuclear cells. H\&E, 200X.

that the activity of catalase but not SOD can be drastically reduced in the presence of superoxide radicals, the generation of which can reach up to $3 \mathrm{nmol} / \mathrm{min}$ under pathological conditions. ${ }^{28}$

These observations are in accordance with those reported by LeBlanc et al, who showed that animals supplemented with lactobacilli with SOD activity were less prone to losing

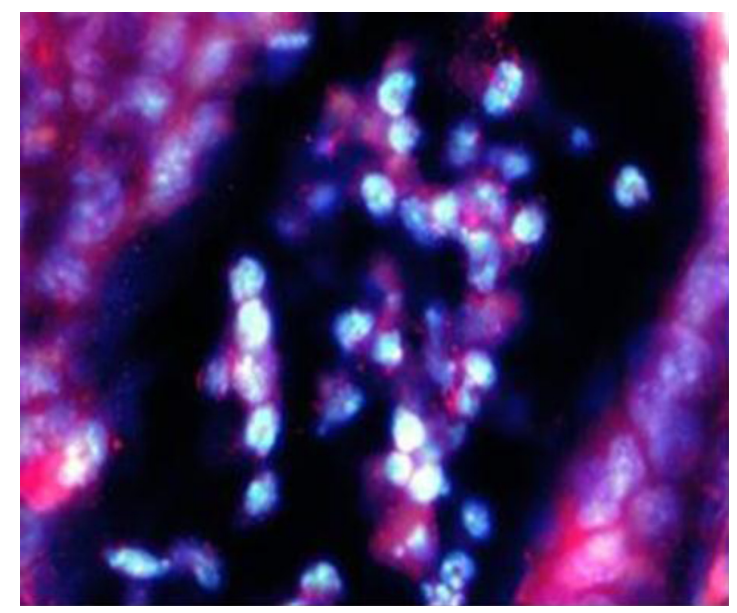

Figure 4 Enterococcus bacteria present in intracryptic abscess in intestines of group IV mice.

Notes: Nuclei of the intestinal epithelial cells stained with the fluorescent stain DAPI, and bacteria of the Enterococcus genus visualized using the Ent probe, labeled with CY3. Magnification I,000×. weight after 5-7 days of trinitrobenzenesulfonic acid (TNBS) administration. ${ }^{29}$ More importantly, 10 days after TNBS treatment, there were no differences in body mass between the experimental and control groups. Our study occurred over the same time period, 5-10 days, and we obtained similar results; the animals receiving both studied strains also showed a slight body mass increase after 10 days.

Mice in group I developed transient intestinal inflammation when they were about 8 weeks old, and it lasted for approximately two more weeks. Over the following experimental days, we observed a gradual recovery to the initial state and did not observe any clinical or histopathological signs of IBD. This course of intestinal inflammation has been previously described in the $\mathrm{C} 57 \mathrm{Bl} / 6 \mathrm{~J}$ mouse IL- $10^{-/-}$line. ${ }^{10}$ To produce an aggressive form of IBD, these mice need to be infected by pathogens such as Helicobacter hepaticus or Enterococcus faecalis; however, the less severe form of inflammation more closely resembles human ulcerative colitis. ${ }^{30}$ Oral administration of L. plantarum 30B strains or a mixture of both lactobacilli strains (L. plantarum 30B and L. acidophilus 900) worsened the health of the mice in the later phase of the experiment. The mice displayed a decrease in body mass and temperature and aggravated histopathological intestinal inflammation was noted. These effects were unexpected, but it may be explained by too high dosage of the 
Lactobacillus bacteria which antigens like as peptidoglycan and exopolysaccharides might stimulate the mucosal immune system and trigger the inflammation. Other authors who used similar mouse model also observed that the conditions of their mice worsened, but did not improve, in the later stages of the experiment (over 5 weeks). Administration of the complex mixture of probiotic preparation VSL \#3 also did not reduce the inflammatory reaction. ${ }^{31}$ Carroll et al observed that administration of high doses of L. gasseri triggered the progression of the inflammatory state, which they described as the development of an aggressive form of intestinal inflammation after introduction of a significant antigenic stimulus. ${ }^{10}$ It should be mentioned that the clinical status worsened and mortality rate increased as inflammation progressed in this mice model. This explains why the progress involved also control animals.

In mice supplemented with both strains of lactobacilli, we observed quantitative changes in the numbers of these bacterial groups, the overgrowth of which is related to the worsening of the intestinal inflammation. Thus, there was a significant increase in the populations of Enterobacteriaceae and Enterococcus. According to the literature, an increase in the number of Gram-negative bacteria located in the intestinal lumen, especially E. coli, is a biological marker of inflammation, which causes fecal occult blood. ${ }^{14}$

Group IV mice were in the worst condition, which was indicated by their high mortality rate $(60 \%)$. In all mice of this group, we observed intracryptic abscesses containing enterococci, which indicates acute inflammation in the intestinal wall. Bacteria from the Enterococcus genus are known to induce intestinal inflammation in this mouse model. ${ }^{32}$ Huycke et al have demonstrated that $E$. faecalis produces large quantities of superoxide anion radical in the intestines, which damages the intestinal epithelium. ${ }^{33}$ This observation may explain the formation of intracryptic abscesses in the intestinal wall of IL-10 $0^{-/}$mice. It is known that the formation of abscesses is characteristic of infections caused by Gram-positive cocci, such as Staphylococcus spp. and Enterococcus spp., and their toxins. ${ }^{34}$ Indeed, using FISH, we demonstrated that the intracryptic abscesses in mice showed high numbers of enterococci.

In spite of the adverse effect of the mixed Lactobacillus strains used by us in this study, we believe that our approach was rational. Moreover, the conclusions of very recent studies of LeBlanc group, although based on genetically modified lactobacilli, show the importance of using mix microorganisms with different single properties to increase the individual effects and to include more than one mechanism of action to ameliorate mucosal inflammation. ${ }^{35}$ Future studies will be needed to estimate optimal dosage of the Lactobacillus strains, both given alone or in a mixture, since all groups supplemented with lactobacilli developed more severe inflammation as observed by histopathological examination than those getting no bacteria. This may indicate that the bacterial load was too high and caused untowarded inflammatory reaction. It is also possible that increased inflammatory response to bacterial load in experimental groups of the animals and also in controls could be a specificity of the selected animal model since most of aggravated reactions and deaths occurred in last days of the observation, ie, in day 18th and later. Therefore, future studies should clarify the optimal time of observations for IL-10 $0^{-/-}$line in $\mathrm{C} 57 \mathrm{Bl} / 6 \mathrm{~J}$ mouse and/ or should be performed on another animal model.

\section{Conclusion}

Our study results demonstrate that it is possible to use selected lactobacilli with antioxidative properties related to dismutase activity to alleviate at least some symptoms associated with IBD. Moreover, our results specifically identified the L. acidophilus 900 strain with high dismutase-like activity as a promising strain, which can be further tested. In summary, Lactobacillus strains that transform superoxide anion radical are more effective in alleviating intestinal inflammation in an IBD mouse model than the strains producing catalase, suggesting that superoxide anion radical is a more toxic ROS than $\mathrm{H}_{2} \mathrm{O}_{2}$.

\section{Acknowledgment}

This work was supported by the Polish National Science Center grants: (N N401144638) and (2014/15/B/NZ6/01856).

\section{Author contributions}

ATP analyzed the antioxidative properties of Lactobacillus strains and wrote the manuscript; MS designed the experiments and was responsible for the final content of this article; $\mathrm{PBH}$ and PJT were involved in the concept and design of the study; BS performed the studies on animals and helped to draft the manuscript; $A B$ was responsible for statistical analysis; KO was responsible for histopathological examination and interpretation of results; all authors read and approved the final manuscript.

\section{Disclosure}

The authors report no conflicts of interest in this work.

\section{References}

1. Scharl M, Rogler G. Inflammatory bowel disease pathogenesis: what is new? Curr Opin Gastroenterol. 2012;28(4):301-309.

2. Zhang YZ, Li YY. Inflammatory bowel disease: pathogenesis. World J Gastroenterol. 2014;20(1):91-99. 
3. Strus M, Janczyk A, Gonet-Surowka A, et al. Effect of hydrogen peroxide of bacterial origin on apoptosis and necrosis of gut mucosa epithelial cells as a possible pathomechanism of inflammatory bowel disease and cancer. J Physiol Pharmacol. 2009;60(Suppl 6):55-60.

4. Rochat T, Bermúdez-Humarán L, Gratadoux JJ, et al. Anti-inflammatory effects of Lactobacillus casei BL23 producing or not a manganesedependant catalase on DSS-induced colitis in mice. Microb Cell Fact. 2007;6:22.

5. Kruidenier L, Kuiper I, Lamers CB, Verspaget HW. Intestinal oxidative damage in inflammatory bowel disease: semi-quantification, localization, and association with mucosal antioxidants. J Pathol. 2003; 201(1):28-36.

6. Martín R, Miquel S, Ulmer J, et al. Role of commensal and probiotic bacteria in human health: a focus on inflammatory bowel disease. Microb Cell Fact. 2013;12:71.

7. Barnese K, Gralla EB, Valentine JS, Cabelli DE. Biologically relevant mechanism for catalytic superoxide removal by simple manganese compounds. Proc Natl Acad Sci U S A. 2012;109(18):6892-6897.

8. Miriyala S, Spasojevic I, Tovmasyan A, et al. Manganese superoxide dismutase, MnSOD and its mimics. Biochim Biophys Acta. 2012; 1822(5):794-814.

9. Kono Y, Fridovich I. Functional significance of manganese catalase in Lactobacillus plantarum. J Bacteriol. 1983;155(2):742-746.

10. Carroll IM, Andrus JM, Bruno-Bárcena JM, et al. Anti-inflammatory properties of Lactobacillus gasseri expressing manganese superoxide dismutase using the interleukin 10-deficient mouse model of colitis. Am J Physiol Gastrointest Liver Physiol. 2007;293(4):G729-G738.

11. Han W, Mercenier A, Ait-Belgnaoui A, et al. Improvement of an experimental colitis in rats by lactic acid bacteria producing superoxide dismutase. Inflamm Bowel Dis. 2006;12(11):1044-1052.

12. Watterlot $\mathrm{L}$, Rochat $\mathrm{T}$, Sokol $\mathrm{H}$, et al. Intragastric administration of a superoxide dismutase-producing recombinant Lactobacillus casei BL23 strain attenuates DSS colitis in mice. Int J Food Microbiol. 2010; 144(1):35-41.

13. Mishra V, Shah $\mathrm{C}$, Mokashe N, et al. Probiotics as potential antioxidants: a systematic review. J Agric Food Chem. 2015;63(14):3615-3626.

14. Strus M, Gosiewski T, Fyderek K, et al. A role of hydrogen peroxide producing commensal bacteria present in colon of adolescents with inflammatory bowel disease in perpetuation of the inflammatory process. J Physiol Pharmacol. 2009;60(Suppl 6):49-54.

15. Büchler G, Wos-Oxley ML, Smoczek A, et al. Strain-specific colitis susceptibility in IL10-deficient mice depends on complex gut microbiota-host interactions. Inflamm Bowel Dis. 2012;18(5):943-954.

16. Barnett MP, Mcnabb WC, Cookson AL, et al. Changes in colon gene expression associated with increased colon inflammation in interleukin-10 gene-deficient mice inoculated with Enterococcus species. BMC Immunol. 2010;11:39.

17. Hansen JJ, Holt L, Sartor RB. Gene expression patterns in experimental colitis in IL-10-deficient mice. Inflamm Bowel Dis. 2009;15(6): 890-899.

18. Maharshak N, Packey CD, Ellermann M, et al. Altered enteric microbiota ecology in interleukin 10-deficient mice during development and progression of intestinal inflammation. Gut Microbes. 2013;4(4): 316-324.

19. Hausler WJ. Standard Methods for the Examination of Dairy Products. 13th ed. Washington, DC: American PublicHealth Association; 1972.
20. Walter J, Tannock GW, Tilsala-Timisjarvi A, et al. Detection and identification of gastrointestinal Lactobacillus species by using denaturing gradient gel electrophoresis and species-specific PCR primers. Appl Environ Microbiol. 2000;66(1):297-303.

21. Asseman C, Mauze S, Leach MW, Coffman RL, Powrie F. An essential role for interleukin 10 in the function of regulatory $\mathrm{T}$ cells that inhibit intestinal inflammation. $J$ Exp Med. 1999;190(7):995-1004.

22. Jansen GJ, Mooibroek M, Idema J, Harmsen HJ, Welling GW, Degener JE. Rapid identification of bacteria in blood cultures by using fluorescently labeled oligonucleotide probes. J Clin Microbiol. 2000; 38(2):814-817.

23. Harmsen HJM, Elfferich P, Schult F. A16S rRNA-targeted probe for detection of lactobacilli and enterococci in faecal samples by fluorescent in situ hybridization. Microbiol Ecol Health Dis. 1999;11:3-12.

24. Wellinghausen N, Bartel M, Essig A, Poppert S. Rapid identification of clinically relevant Enterococcus species by fluorescence in situ hybridization. J Clin Microbiol. 2007;45(10):3424-3426.

25. Reiff C, Delday M, Rucklidge G, et al. Balancing inflammatory, lipid, and xenobiotic signaling pathways by VSL\#3, a biotherapeutic agent, in the treatment of inflammatory bowel disease. Inflamm Bowel Dis. 2009;15(11):1721-1736.

26. Wang LX, Liu K, Gao DW, Hao JK. Protective effects of two Lactobacillus plantarum strains in hyperlipidemic mice. World J Gastroenterol. 2013;19(20):3150-3156.

27. Zanoni S, Pompei A, Cordisco L, et al. Growth kinetics on oligo- and polysaccharides and promising features of three antioxidative potential probiotic strains. J Appl Microbiol. 2008;105(5):1266-1276.

28. Rahman K. Studies on free radicals, antioxidants, and co-factors Clin Interv Aging. 2007;2(2):219-236.

29. Leblanc JG, del Carmen S, Miyoshi A, et al. Use of superoxide dismutase and catalase producing lactic acid bacteria in TNBS induced Crohn's disease in mice. J Biotechnol. 2011;151(3):287-293.

30. Valatas V, Vakas M, Kolios G. The value of experimental models of colitis in predicting efficacy of biological therapies for inflammatory bowel diseases. Am J Physiol Gastrointest Liver Physiol. 2013;305(11): G763-G785.

31. Arthur JC, Gharaibeh RZ, Uronis JM, et al. VSL\#3 probiotic modifies mucosal microbial composition but does not reduce colitis-associated colorectal cancer. Sci Rep. 2013;3:2868.

32. Balish E, Warner T. Enterococcus faecalis induces inflammatory bowel disease in interleukin-10 knockout mice. Am J Pathol. 2002; 160(6):2253-2257.

33. Huycke MM, Abrams V, Moore DR. Enterococcus faecalis produces extracellular superoxide and hydrogen peroxide that damages colonic epithelial cell DNA. Carcinogenesis. 2002;23(3):529-536.

34. Brook I. Microbiology and management of abdominal infections. Dig Dis Sci. 2008;53(10):2585-2591.

35. del Carmen S, de Moreno de Leblanc A, Levit R, et al. Anti-cancer effect of lactic acid bacteria expressing antioxidant enzymes or IL-10 in a colorectal cancer mouse model. Int Immunopharmacol. 2017;42: $122-129$.

\section{Publish your work in this journal}

Drug Design, Development and Therapy is an international, peerreviewed open-access journal that spans the spectrum of drug design and development through to clinical applications. Clinical outcomes, patient safety, and programs for the development and effective, safe, and sustained use of medicines are the features of the journal, which

\section{Dovepress}

has also been accepted for indexing on PubMed Central. The manuscript management system is completely online and includes a very quick and fair peer-review system, which is all easy to use. Visit http://www.dovepress.com/testimonials.php to read real quotes from published authors. 